Tammy Gregersen

American University of Sharjah, UAE

Peter D. MacIntyre

Cape Breton University, Canada

Rachel Buck

American University of Sharjah, UAE
iD https://orcid.org/0000-0003-0744-9655

iD https://orcid.org/0000-0002-1085-6692

iD https://orcid.org/0000-0001-7257-5506

\title{
Using Character Strengths to Address English Writing Anxiety
}

\begin{abstract}
Positive psychology has been introduced to the applied linguistics literature with the broad goal of improving the experience of language learners and teachers through a variety of interventions (MacIntyre \& Mercer, 2014; Gabryś-Barker \& Gałajda, 2016). "The aim of positive psychology is to catalyze a change in psychology from preoccupation only with repairing the worst things in life to also building the best qualities in life" (Seligman \& Csikszentmihalyi, 2000, p. 5). One significant contribution of this young field has been a series of empirically-tested positive psychology interventions (PPIs) that have been shown to increase positive emotion, reduce distress, and/or improve well-being (Seligman, Steen, Park, \& Peterson, 2005; Sin \& Lyubormirsky, 2009). In the present research, we examine one application of a PPI involving a focus on using character strengths as a way to address language anxiety. Through a case study analysis, we demonstrate the ways that this intervention was beneficial for the student.
\end{abstract}

Keywords: foreign language anxiety, positive psychology interventions (PPIs), VIA Strengths Inventory

The literature on positive psychology has proposed a number of exercises or interventions that have been empirically shown to increase well-being. However, one of the early important lessons emerging in studies of positive psychology interventions (PPIs) in language acquisition is that the efficacy of the interventions appears to be quite variable, depending to a large degree on the individual and their context. For example, PPIs have been used to encourage emotional intel- 
ligence traits, such as gratitude, savoring, and optimism (Gregersen, MacIntyre, Finegan, Talbot, \& Claman, 2014); empathy and emotional labor (Gregersen, MacIntyre, \& Macmillan, 2020); gratitude, altruism, music, exercise, pets, and laughter (Gregersen, MacIntyre, \& Meza, 2016). These characteristics are especially important in the foreign language classroom. There are positive benefits to connecting emotional intelligence and foreign language enjoyment (Aki, 2006) and can have a predictive effect on language performance (Valizadeh \& Alavinia, 2012; Zarafshan \& Ardeshiri, 2012). Although language anxiety has been studied extensively and potential interventions have been proposed, there are still few empirically tested examples.

In the present research, we take an N-of-1 experimental approach to examine the effectiveness of a PPI by using character strengths in a new way as a factor in reducing anxiety. We focus specifically on the skill of writing and examine whether the learner's novel engagement of self-selected character strengths might reduce language anxiety and help improve performance in a second language writing class.

\section{Positive Psychology and PPIs}

Succinctly, positive psychology can be defined as "the scientific study of what goes right in life" (Peterson, 2006, p. 4). Whereas much of psychology is concerned with negative experiences such as depression, trauma, and anxiety, positive psychology encourages a balance among research topics that directs research effort toward the breadth of the human experience-good and badacknowledging that good health means much more than the mere absence of illness (Seligman \& Csikzentmihalyi, 2000, p. 5). The obvious parallel in SLA is the notion that language learners are not deficient native-language (L1) speakers, but, rather, are developing unique linguistic and communicative capabilities (Byrnes, 2018). At the same time, positive psychology advocates applying the rigor of the scientific method that psychology has long employed-which demands testing theories against evidence. Accordingly, positive psychology is not to be mistaken for untested pop psychology, groundless assertions, or simplistic promotion of the power of positive thinking. Rather, it requires an empirical process that demands scientific methods, falsifiability, and attention to methods, whether quantitative or qualitative (Hefferon, Ashfield, Waters, \& Synard, 2017). In particular, the literature on positive psychology can benefit from engaging a combination of experimental and qualitative designs to produce a process-oriented account of how and why a specific PPI might work for a specific person. 
The development of positive psychology interventions (PPIs) includes exercises, training, and therapies principally focused on increasing positive feelings, positive cognitions, or positive behavior, in contrast to interventions that target a reduction of unpleasant symptoms. The typical approach of a PPI is to encourage further development and new applications of processes that already produce positive effects for a person. Available, systematic evidence shows that PPIs can be effective (Seligman et al., 2006; Sin \& Lyubomirsky, 2009). Seligman et al. (2005) identified five specific exercises emphasizing positivity that also resulted in reducing depression and/or increasing well-being over short term and long term follow-up has been supported by random placebo-controlled trials. The five exercises asked participants, every day for a week, to (1) name three good things every day; (2) express gratitude more often; (3) describe 'you' at your best; (4) identify personal character strengths, and (5) use their strengths in new ways.

The fifth exercise, using strengths in new ways, produced a pronounced reduction in depressive symptoms and an increase in self-reported happiness after a week, one month, three months and at the six-month follow-up. As part of the follow-up process, the researchers asked the study participants whether they continued to use the PPI even after the one-week intervention portion of study was complete. Those who continued to use the exercise on their own experienced the most pronounced positive effects over time, emphasizing the need for a 'fit' between the person and the intervention activity (Lyubormirsky \& Layous, 2013). The present study tests this intervention's effects on second language writers, with particular emphasis on one person who was most successful in engaging with the PPI.

The methodological toolbox that can be used to evaluate PPIs is diverse. One under-utilized approach is single-subject or N-of-1 designs that test one individual intensively, over time. N-of-1 designs are especially valuable in testing PPIs because results at the group level may or may not apply to specific individuals and vice versa. Further, analyzing individual-level data can reveal details of the process of using PPIs that cannot be examined at the group level. In general, most PPIs, including the novel use of signature strengths employed here, usually are framed as an outline of activity and processes that must be tailored to individuals. Woodworth et al. (2015) provide an example of testing PPIs in N-of-1 designs. They argue that studying individuals, rather than drawing conclusions from group averages, is advantageous for at least three reasons: (1) relevant changes in psychological states can be identified that might be missed when averaged over a group; (2) interventions often are adapted to be tailored to an individual's context; and (3) N-of-1 actually is a preferred design when an intervention is used repeatedly over time, providing a more rigorous test of the effect of the intervention. The study by Woodworth et al. provided evidence that using signature strengths is one of the more effective interven- 
tions but that there is considerable variability in the effect of PPIs for individuals. In general, Woodworth et al. conclude that PPIs are likely most effective when there is a good fit between the person and the activity, but, at the same time, the authors show that such a result is problematic because the effectiveness of PPIs "[...] should not rely on the self-selection of participants" (2015, p. 28). We disagree. Perhaps the more appropriate lesson from Woodworth et al. is not about the decontextualized efficacy of any given PPI in general but, rather, the need to assess how the process of using a PPI reveals its fit with the person using it and the context in which they live. In the case of the PPI under study here, the specific signature strength, or, more broadly, the pattern of interconnected strengths, will be unique to each person, and using strengths in a novel way is a creative process that would not be instantiated in the same way in another person.

\section{Signature Strengths}

Character strengths are often defined in ways similar to personality traits, specifically as the capacity for thoughts, feelings, and actions that allow for optimal functioning in ways that are valued, either because of goal orientations or morally-valued virtues (Biswas-Diener, Kashdan, \& Minhas, 2011; Linley, Maltby, Wood, Joseph, Harrington, Peterson, \& Seligman, 2007). Consistent with modern personality trait theory, strengths can be viewed as "stable and general but also shaped by the individual's setting and thus capable of change" (Peterson \& Seligman, 2004, p. 10).

One of the most widely used ways of measuring strengths is the online VIA inventory (Peterson \& Seligman, 2004). Seligman (2002) defines the qualities of a character strength as the ability to: (1) contribute to individual fulfillment, satisfaction, and happiness; (2) be advocated by institutions (e.g., schools, religions); (3) be associated with respected persons; and (4) be morally valued in its own right and not for tangible outcomes it may produce. Further, from a research perspective, strengths are defined as trait-like, measurable, and nonredundant with other character strengths. Theoretically, a taxonomy of potential strengths that are ubiquitous across cultures identified 24 character strengths divided into six broader categories called virtues (Peterson \& Seligman, 2004). The six virtues and the character strengths that fall within each are:

1. Wisdom/Knowledge: creativity, curiosity, judgment, love of learning, and perspective;

2. Courage: bravery, perseverance, honesty, and zest;

3. Humanity: love, kindness, and social intelligence; 
4. Justice: fairness, leadership, and teamwork;

5. Temperance: forgiveness, humility, prudence, and self-regulation;

6. Transcendence: appreciation of beauty/excellence, gratitude, hope, humor and spirituality.

Research that has tested the reliability and validity of the VIA Inventory has suggested that the individual scales show acceptability, reliability, and validity (McGrath, 2016; Peterson, Park, \& Seligman, 2006). ${ }^{1}$

To emphasize that some strengths are more influential than others in a person's life, Seligman (2002) coined the term signature strengths to identify those that best characterize a person. Seligman (2002) describes signature strengths as those meeting the following criteria:

- a sense of ownership and authenticity surrounding the strength;

- a feeling of excitement (particularly at first) while displaying it;

- create a rapid learning curve when undertaking new tasks;

- intrinsic motivation to use the strength;

- a sense of yearning to act in accordance with it;

- the creation and pursuit of fundamental projects that revolve around the strength;

- continuous learning of new ways to use the strength;

- invigoration rather than exhaustion when using the strength;

- the discovery of the strength as owned in an epiphany;

- a feeling of inevitability in using the strength (i.e., "try and stop me").

The above attributes, including intrinsic motivation, excitement, and rapid learning, would likely be welcomed in almost any pedagogical context by teachers and learners alike.

In considering how strengths are employed in situ, Biswas-Diener et al. (2011) emphasize the need to take a dynamic view of strengths.

Instead of focusing on strengths as internal capacities that exist across time and situations (contemporary trait approach), we adopt a dynamic, withinperson approach to personality. Instead of searching for behaviors that elicit strong performance and vitality across time and situations, we can search for interactions between people and their environment. Such behaviors can be defined as a strength-based structure within someone's personality. (p. 110)

The specific intervention employed in the present study shows promise in aligning the specific strengths of an individual with difficulties they might be having, specifically anxiety-arousal. The intervention has two parts. First, each participant identifies his or her own personal strengths, using a standardized

${ }^{1}$ Empirical research is showing that these can be organized differently (McGrath, 2015) and there are now several variations on the VIA inventory available (www.viacharacter.org). 
survey published online called the VIA Inventory (Peterson \& Seligman, 2004). Second, the person is tasked with creating new ways to optimize personal well-being by finding new ways to apply the strength in areas where it has not been applied in the past.

\section{Language Anxiety}

Anxiety is often a disruptive and an unwelcome part of the languagelearning process. Defined as "a distinct complex of self-perceptions, beliefs, feelings, and behaviors related to classroom language learning arising from the uniqueness of the language learning process" (Horwitz et al., 1986, p. 128), this anxiety can often hinder the learner's progress. Numerous studies have raised concerns about the negative effects of anxiety arousal (for reviews see: Horwitz, 2017; MacIntyre, 1999; 2017; Teimouri, et al., 2019), including studies highlighting negative effects of anxiety on the writing process (Cheng, Horwitz, \& Schallert, 1999; Cheng, 2002; Lee \& Krashen, 1997). In broad terms, we can identify two possible routes by which to reduce anxiety: (1) directly address the symptoms of anxiety, for example, through relaxation training or eliminating anxiety triggers (see Gregersen \& MacIntyre, 2014 for several suggestions), or (2) intervene in a way that affects anxiety as a byproduct of focus on other attributes, for example, through building strengths and self-confidence (see Dewaele \& Dewaele, 2017). If we choose to leave anxiety to one side and work on interventions that psychologically build up the learner, a collection of empirically tested PPIs is available, though none has been tested as a way to reduce the negative effects of language anxiety (Seligman, Steen, Park, \& Peterson, 2005; Sin \& Lyubormirski, 2009; Helgesen, 2018).

However, at the outset of this research, we take note that studies exploring the efficacy of positive psychology interventions (PPIs) in Second Language Acquisition (SLA) suggest that their success is quite variable across individuals (Gregersen, MacIntyre, Finegan, Talbot, \& Claman, 2014; Gregersen, MacIntyre, \& Macmillan, 2020; Gregersen, MacIntyre, \& Meza, 2016). There are myriad reasons for anxiety arousal, and this is important to recognize because the reason for anxiety may influence the configuration of individuals' abilities or aptitudes that are relevant to the success of any specific intervention (Gregersen \& MacIntyre, 2014).

In the present study, we take a process-oriented, N-of-1 approach to an experimental procedure wherein English language learners were tasked with identifying their signature strengths using the VIA online survey (Peterson \& Seligman, 2004) and explore whether using them helped to reduce anxiety in 
a writing course. Because anxiety is personal, students were told they would be using these strengths to overcome their individual senses of anxiety. Over a three-week period, learners self-generated ways of using their own strengths in new ways as they approached writing tasks in their language course. Participants used three specially created narrative frames (Burkhuizen \& Wette, 2008) before, during, and after the intervention to capture their thoughts about their past, present, and future use of their signature strengths (See Appendix A). Although we will test differences in anxiety based on the Second Language Writing Anxiety Inventory (SLWAI) results (Cheng, 2004), our concern with a process-oriented account suggests that the intervention be examined as a case study. In particular, we focus on how the learner who was most successful in reducing writing anxiety used their signature strengths. A close examination of the case study participant's narrative frames and four individual written assignments before and during the intervention offers insight into whether the intervention influenced that individual's writing.

In short, our research questions are as follows:

RQ1: How did learners react in general to the PPI which required using signature strengths in new ways; what did students say about the activity in their narrative frames?

RQ2: What can a close examination of one particular case study participant, who experienced success with using signature strengths in new ways, reveal about the potential found in the intervention to mitigate the effects of negative emotion?

\section{Methodology}

\section{Participants}

A total of 45 participants (24 females, 21 males) were recruited for this study. All were first- and second-year university students from a variety of majors (several different kinds of engineering, biology, architecture, design, finance, business, marketing, mass communications, international studies) enrolled in three different sections of an obligatory English for academic writing class. The class is the first of three writing courses that they must take at a university in the United Arab Emirates (UAE). Two of the three intact course sections became experimental groups (31 participants), while the third acted as a control (14 participants). Although the language of instruction for 
all of the classes and the university was English, the L1 of the majority was Arabic (38), followed by Urdu (3), Malayalam (2), Tajik (1), and Gujarati (1). The UAE has an unusual sociolinguistic context in that it has welcomed globalization by adopting English through the implementation of a strategy of linguistic dualism in which English is linked with commercial, modern, and international facets of society, while Arabic is used in religious, traditional, and local aspects (Findlow, 2006).

\section{Instruments}

The VIA Inventory of Strengths. To assess participants' character strengths we used the English version of Seligman and Peterson's (2004) standardized web-based VIA Inventory of Strengths, that according to the survey's website, has been taken by over seven million people (https://www.viacharacter. org/www/). The VIA is a self-report survey in which participants rank their responses to items on a five-point scale $(1=$ "not at all like me," $5=$ "very much like me"). With a total of 198 items (five to nine statements per strength), respondents report their degree of support for each statement and then receive a report, free of charge, which lists all 24 character strengths in order from the individual's strongest to weakest.

The L2 Writing Anxiety Inventory (Cheng, 2004). To assess participants' L2 writing anxiety, we used Cheng's (2004) Second Language Writing Anxiety Inventory whose total scale and subscales were assessed by means of correlation and factor analysis. It was discovered that both the total scale and the individual subscales of the SLWAI have good reliability and adequate validity. Consisting of 22 Likert-type items ranging from 1 (strongly disagree) to 5 (strongly agree), the Inventory was created for the purpose of developing and evaluating a self-report assessment that reflects a three-dimensional conceptualization of anxiety. The three components assessed by the items are: (a) cognitive, reflecting the mental aspect of the anxiety experience, including negative expectations, preoccupation with performance and concern about others' perceptions; (b) somatic, including one's awareness of the physiological effects of the anxiety experience, as reflected in increased arousal of unpleasant feelings, such as nervousness and tension; and (c) avoidance behavior, which is the behavioral aspect of avoiding writing.

Narrative frames. Our third set of instruments, three different narrative frames (See Appendix A), was used to document participants' feelings before applying their strengths, how they felt during the exercise, and their resulting feelings upon completion. The pre- and post-intervention narrative frames were each filled out once, while the "during-the-intervention" one was completed nine times, corresponding to the three times a week class was held for 
the experimental period of three weeks. The narrative frames were meant to provide guidance and support in terms of both the structure and connection for their written narratives (Barkhuizen \& Wette, 2008). Narrative frames as a research method deliver a snapshot of participants' experiences in the form of a story, written mostly by the participants within a framework provided by the researcher. For the purposes of this study, the three frames acted as starters, connectives, and sentence modifiers, giving participants a template within which they could focus on communicating what they sought to convey while, at the same time, scaffolding them with a specific generic form.

Coded writing assignments. Our fourth data set consisted of four formal written assignments that were submitted throughout the semester, although the intervention began during week 10 of the semester. Table 1 shows the study intervention process within the semester timeline.

Table 1.

Data collected from students in experimental group

\begin{tabular}{|c|c|c|c|}
\hline $\begin{array}{l}\text { Study } \\
\text { week \# }\end{array}$ & Intervention data collected & $\begin{array}{l}\text { Semester } \\
\text { week \# }\end{array}$ & Syllabus assignment data collected \\
\hline & & & $\begin{array}{l}\text { Pre-Intervention: students had already } \\
\text { completed a Disciplinary Writing } \\
\text { Analysis and had begun research } \\
\text { about their chosen research topic. }\end{array}$ \\
\hline 1 & $\begin{array}{l}\text { VIA Character Strengths test, the } \\
\text { Pre-Intervention SLWAI; and the } \\
\text { Pre-Intervention Narrative Frame. }\end{array}$ & 10 & $\begin{array}{l}\text { Students had completed an Annotated } \\
\text { Bibliography assignment for an } \\
\text { Introductory Research Paper (Syllabus } \\
\text { Assignment \#2); they began drafting } \\
\text { an introduction for this paper. }\end{array}$ \\
\hline 2 & $\begin{array}{l}\text { During-Intervention Narrative Frame } \\
\text { with responses for } 3 \text { days of the } \\
\text { week. }\end{array}$ & 11 & $\begin{array}{l}\text { Students began an outline and draft } \\
\text { for their research papers. }\end{array}$ \\
\hline 3 & $\begin{array}{l}\text { During-Intervention Narrative Frame } \\
\text { with responses for } 3 \text { days of the } \\
\text { week. }\end{array}$ & 12 & $\begin{array}{l}\text { Students submitted their research } \\
\text { papers and began the Introductory } \\
\text { Argument Assignment (Syllabus } \\
\text { Assignment \#3). This assignment } \\
\text { was a "Letter to the Editor" based } \\
\text { on the research they had completed } \\
\text { for Assignment \#2. }\end{array}$ \\
\hline 4 & $\begin{array}{l}\text { During-Intervention Narrative Frame } \\
\text { with responses for } 3 \text { days of the } \\
\text { week. }\end{array}$ & 13 & $\begin{array}{l}\text { Students } \quad \text { submitted Argument } \\
\text { Assignment (Syllabus Assignment \#3). }\end{array}$ \\
\hline 5 & Post-Intervention SLWAI. & 14 & $\begin{array}{l}\text { Students began working on the Final } \\
\text { Reflection (Syllabus Assignment \#4). }\end{array}$ \\
\hline 6 & $\begin{array}{l}\text { Students were shown the Pre- and } \\
\text { Post-SLWAI scores and submitted } \\
\text { a short reflection commenting on the } \\
\text { change or lack of change. }\end{array}$ & 15 & $\begin{array}{l}\text { Students submitted the Final } \\
\text { Reflection Assignment (Syllabus } \\
\text { Assignment \#4). }\end{array}$ \\
\hline
\end{tabular}


The written formal assignments were the following:

Assignment 1. Rhetorical analysis paper. Purpose: to analyze the rhetorical situation and particular rhetorical strategies of a genre from the student's discipline, such as an engineering proposal.

Assignment 2. Introductory research paper. Purpose: to research a chosen topic and present many aspects of the issue. Students included a cover letter with their paper to encourage meta-cognitive awareness.

Assignment 3. Letter to the editor. Purpose: students chose a newspaper or magazine and wrote an opinion piece using research from their previous class assignments.

Assignment 4. Course reflection. Purpose: to retroactively review their assignments and demonstrate that they learned valuable skills which they will transfer to future contexts.

Post-study Reflection/Member Check. At the end of the intervention period and upon being informed of their pre- and post-intervention SLWAI scores, the participants were asked to reflect upon their results and reveal any insight they may have as to why the differences occurred. Table 2 shows the data collected from the control group students and procedures are explained further in the next section.

Table 2.

Data collected from students in control group

\begin{tabular}{llcl}
\hline $\begin{array}{c}\text { Study } \\
\text { week \# }\end{array}$ & $\begin{array}{c}\text { Intervention data collected from } \\
\text { students in control group }\end{array}$ & $\begin{array}{c}\text { Semester } \\
\text { week \# }\end{array}$ & $\begin{array}{c}\text { Syllabus assignment data collected } \\
\text { from students in control group }\end{array}$ \\
\hline 1 & $\begin{array}{l}\text { Students completed Pre-Intervention } \\
\text { SLWAl. }\end{array}$ & 10 & $\begin{array}{l}\text { Students completed the same as- } \\
\text { signments as the experimental group, } \\
\text { but these were not collected. }\end{array}$ \\
5 & $\begin{array}{l}\text { Students completed the Post- } \\
\text { Intervention SLWAl. }\end{array}$ & & \\
& $\begin{array}{l}\text { Students were shown the Pre- and } \\
\text { Post-SLWAI scores and submitted } \\
\text { a short reflection commenting on the } \\
\text { change or lack of change. }\end{array}$ & & \\
\end{tabular}

\section{Procedures}

Data collection for the experimental and control groups took place over the course of six weeks after students consented to participate in the study. After this, participants across the three groups responded to the pretest SLWAI. Subsequently, only the experimental group participated in the intervention while participants in the control group continued with class as usual without using their signature strengths in new ways. 
The first activity completed by the experimental group, outside class time, was the online VIA Character Strengths Survey with the purpose of revealing their personal strengths used most often. Upon receiving their personalized strengths report from the VIA website, experimental participants filled out the first ("pre-intervention") narrative frame called "My Strengths Story."

After submitting the first narrative frame during the next class, participants were asked to think of creative ways to use their strengths throughout the next three weeks, at which point they were given three identical ("duringintervention") narrative frames into which they documented their experiences. This helped participants keep track of how they applied their strengths on a daily basis and how this affected their performance and feelings. The frames prompted participants to write their top five strengths, and then each week to choose one strength and think of novel ways to use it in writing class or while they wrote their assignments outside of class. In this way, each individual participant was able to individualize the intervention to fit their own context.

After completing the during-intervention narrative for three consecutive weeks, students were given their final ("post-intervention") narrative frame which was similar to, but not exactly the same, as the first. This one asked them to reflect on the similarities and differences in their feelings before and after the intervention by describing how they felt while writing in their L2. They reported on levels of confidence, continuing struggles, and ways they might conquer these struggles by using their signature strengths in the future. They completed the post-intervention narrative frame in class and then took the post-test SLWAI. Control group participants also took the post-SLWAI. The scores of both the control and experimental groups' SLWAI were then calculated for each participant to identify individuals showing the most anxiety reduction. In week 6 of the study, students from the experimental group were informed about the difference between their pre- and post- SLWAI scores and were asked to write a short reflection about changes in their personal anxiety scores.

To focus on the N-of-1 analysis, we selected the participant who showed the greatest change in SLWAI scores in order to assess the specific ways in which she used the PPI to reduce anxiety. The analysis examined her four formal writing assignments that had been submitted during the semester in the context of the writing class. Using an iterative coding process, two coders were given copies of the case study participant's three sets of narrative frames as well as her four written papers and were instructed to identify evidence supporting the participant's strength being incorporated into her writing. Using five different-colored highlighters for the participant's five character strengths, readers coded the presence of the strength in the participant's manuscripts. For example, if the participant stated in her narrative frame that she would use her "zest" to "create an anecdote in her introduction," readers coded the strength of "zest" in pink and then highlighted the anecdote in the corresponding written 
assignment also in pink. Only those narratives that had sections coded by both readers in the same color are used as data in this study.

\section{Results and Discussion}

To answer RQ1 concerning learners' reaction to using their signature strengths in new ways, we begin with the narrative frames. The participants in the intervention group were asked to complete three narrative frames that corresponded to their feelings concerning writing in their L2 (English) before, during and after the intervention (Using Signature Strengths in a New Way). Examination of the respondents' word choice within the narrative frames suggests positive experiences. There were no negative descriptors used in any of the post-intervention narrative frames. All reported feeling positive about engaging their strengths, using adjectives such as powerful, successful, comfortable, confident, amazed, happy, satisfied, humorous, productive, curious, involved, prepared, positive, relieved, dedicated, comfortable, and creative.

The words used in narrative frames generally indicate a positive collective response to the exercise even though it did not result in statistically significant differences between the groups on the writing anxiety measure. ${ }^{2}$ Previous research in positive psychology suggests that a group-level examination can obscure the variability among individual reactions to specific interventions and complicate the identification of the variables that drive change (or lack thereof) within individuals (Gregersen, MacIntyre, \& Macmillan, 2020). Because grouplevel results seldom reflect the experience of individuals, or can be assumed to do so only under restrictive conditions (Molenaar \& Campbell, 2009), we focus on an N-of-1 case study for an individual (Eid \& Diener, 1999; Lazarus, 2003) to show an example of the process of the intervention being used. We selected the participant who showed the single largest decline in writing anxiety among the study participants; we shall call her Noor.

2 The small sample size suggests that the analysis was under-powered, but we present the ANOVA results here for completeness. To assess the group-level effects of the PPI, a $2 \times 2$ split plot (mixed model) ANOVA was conducted. The between-subjects factor was Group (intervention vs control) and the repeated-measures factor was Time (pre-test vs. post-test). The dependent variable was the SLWAI total score. Levene's test was non-significant for both the pre- and post-test data, allowing us to assume homogeneity of variance at each testing time. Results showed no significant main effects or interactions. The main effect for Group, $F(1,39)=.41$, $p=.527$, the main effect of Time, $F(1,39)=2.70, p=.109$, and the Group $\times$ Time interaction, $F(1,39)=.51, p=.481$, all were non-significant. Although both groups showed a slight but non-significant decline in mean anxiety scores (overall Mpre $=61.7$; Mpost $=59.1$ ), the intervention and control groups on average showed approximately the same degree of change over time. 
In response to RQ2 that asks what a close examination of one particular participant might reveal about the potential of the intervention, we turn to the individual chosen as the focus of our in-depth case study, Noor. She was selected based upon the unusual effectiveness of the intervention to mitigate her L2 writing anxiety. Noor had a post-test anxiety score 21 points less than at pretest. This was the largest success of anyone in the study suggesting that she found a fit between her specific context and the way in which she used the signature strengths PPI.

Noor, a design major, speaks Arabic as her L1 and began acquiring English at the age of three as an L2. On a scale of one (low proficient) to ten (high proficient), she self-assessed her English proficiency a bit above average with a 7.5. According to the results of the VIA inventory, her top five strengths (in descending order) were spirituality, creativity, humility, honesty, and zest. Specifically, the strengths are defined as follows:

- A spiritual person is guided by his or her solid, consistent beliefs about the universe's higher purpose and meaning and receives comfort from such beliefs as they evidence where the individual fits into a much bigger picture.

- A creative person constantly imagines novel ways to do things and are seldom satisfied by getting things done via traditional means.

- A humble person is acknowledged and valued for his or her modesty and avoidance of the spotlight.

- An honest person lives authentically, straightforwardly, genuinely, and without pretense.

- A person with zest exudes excitement and energy, living life wholeheartedly and as an adventure (via Institute on Character, 2019).

\section{Before the Strengths Intervention}

The pre-intervention narrative frame shows Noor's thinking before the study began. Her words are italicized below; the un-italicized words are part of the narrative frame:

In my writing class, I have a difficult time trying to find my inner voice. The main reason for this is that I cannot find the right vocab palette to express myself the way I express myself in Arabic. However, I feel I excel in simplifying complex ideas and make them better suited for a wide range of audience. One of my personal strengths is spirituality. I have used it in the past to overcome the losses and disappointments I have faced. This week, I will use my strength to help me in my writing and my writing class by re-reading what I wrote in my introduction and altering it so it matches who I am. Each of the remaining three weeks I will try to use my personal 
strength in a new way by: 1) listening to podcasts to improve it and learn how to efficiently incorporate it in my daily life; 2) finding inspiration from my environment; and 3) reading my audience and friends. [i.e. interpreting friends' reactions to events]

Before beginning the intervention, Noor felt she exceled at simplifying complex ideas but also lamented not having the vocabulary in English that she commands in her L1 (Arabic), which she believes limits her authenticity in English. Her concern over authenticity may be highly salient for her, given that a top strength is being "honest," which by definition means living authentically (via Institute on Character, 2019). Furthermore, she seems to recognize that gaps in her command of English do not allow her to express herself in creative ways, frustrating another of her strengths. Further in the narrative frame, Noor juxtaposes her limited lexicon with notions that are a bit esoteric - she recognizes one of her strengths as spirituality, yet begrudges her difficulties in finding her "inner voice" in her L2 writing, which implicates her strengths of honesty, integrity, and authenticity. Noor uses this disparity to revise her writing in order to align it more with her authentic self. Paired with the strength of spirituality, we might infer that the podcasts to which she plans to listen (as cited in her goal list for the following three weeks) will invoke spiritual messages and that the "inspiration" she seeks from her environment will also provide a spiritual uplift. Noor's pre-intervention narrative reveals an alignment among the difficulties she perceives in her own authentic writing and strengths she can use during the three-week intervention phase of the study.

\section{During the Strengths Intervention}

As part of the intervention, Noor completed nine additional narrative frames, one in each of three classes per week for three weeks. Each narrative frame consisted of three sentences in which the first part of the sentence was provided and she completed the rest. The first narrative frame Noor completed in week 1 is shown here, followed by Table 1, which summarizes verbatim her responses to the same narrative prompts in weeks 2 and 3.

Week 1.

Class 1: The strength I used was creativity. I used this strength in my writing by finding new ways to draw the reader. After doing this, I felt that it is easier to continue my introduction since I have a strong base. 
Class 2: The strength I used was zest. I used this strength in my writing by I finished my introduction wholeheartedly. After doing this, I felt satisfied, since I am a perfectionist.

Class 3: The strength I used was spirituality. I used this strength in my writing by listening to my inner voice, to help organize my ideas, and how my essay will flow. After doing this, I felt blank, since all my thoughts are reflected in my paper.

Table 3.

Case study \#1 (Noor's) during-intervention narrative frame response

\begin{tabular}{|c|c|c|c|}
\hline & $\begin{array}{l}\text { The strength } \\
\text { I used was... }\end{array}$ & $\begin{array}{l}\text { I used this strength in my } \\
\text { writing by... }\end{array}$ & After doing this, I felt... \\
\hline \multicolumn{4}{|c|}{ Week 2} \\
\hline Class 1 & creativity & finding smart arguments & critical thinker \\
\hline Class 2 & honesty & stating $100 \%$ accurate facts & knowledgeable \\
\hline Class 3 & zest & anecdotal introduction & optimistic \\
\hline \multicolumn{4}{|c|}{ Week 3} \\
\hline Class 1 & spirituality & $\begin{array}{l}\text { finding an accurate tone to } \\
\text { address my audience }\end{array}$ & like I sent the message accurately \\
\hline Class 2 & creativity & making an anecdote & $\begin{array}{l}\text { like I killed the idea since its already } \\
\text { created, no room for improvement }\end{array}$ \\
\hline Class 3 & honesty & finding accurate data & unbias \\
\hline
\end{tabular}

During the intervention, Noor found new ways to exercise four of her top five strengths while writing. According to the information in the narrative frames, throughout the three weeks she employed her creativity three times: to draw in her readers, to formulate "smart" arguments, and to compose an anecdote. This strength application resulted in her feeling that the writing process was easier, that she improved her critical thinking, and that she did such a good job there was "no room for improvement." She used honesty to state facts she believed to be $100 \%$ correct and to find accurate data which made her feel "knowledgeable" and "unbiased." Exercising her strength for zest, Noor "wholeheartedly" finished writing an anecdotal introduction, sparking feelings of satisfaction and optimism. Finally, Noor re-visited her spirituality strength by using her inner voice to guide organization of her writing and strike an appropriate tone for her audience.

There are connections between the strengths identified prior to the intervention and the new ways Noor created to use them. Noor experienced positive language results after using her signature strengths in new ways: she liked her writing, feeling optimistic, knowledgeable, and satisfied. These are positive psychological processes that teachers typically encourage in a writing course. In her first (pre-intervention) writing assignment, Noor communicated anxiety 
concerning expressing herself in her English writing. She attributed her apprehension to past educational experiences in which teachers "just taught us to stick to the five paragraph essays where every sentence is calculated, there is little to no space for self-expression, and creative writing." She found the old approach too restrictive; the present approach seemed a better fit to her particular strengths. As a design major, Noor felt the tension between her desire to be creative in her writing and following formulaic, prescribed rules. She stated in her assignment that when she started college, she found it "challenging in adjusting my writing and drawing a line between my design proposal, my WRI 101 essays, and my history classes biography writing" (Assignment 1).

She echoes the sentiments again in her final research paper reflection letter. Within the context of applying strengths such as creativity, she commented, "I learned that there are rules and policies one must abide to when writing a research paper." In essence, Noor suggested that her writing anxiety stems in part from the notion that her past writing experiences did not provide enough room for her to exercise the signature strength of creativity. During the intervention, her narrative frame responses described how she invoked creativity more than any other strength (three times). Further, she suggested that creativity could manifest in different, non-traditional ways. She was able to exercise her strengths within the broader confines of the L2 writing systems she was being taught.

At the outset of the intervention, Noor was in the process of gathering research and drafting a paper on the topic of closed and open adoptions. ${ }^{3}$ In her narrative frame for week 1 of the intervention, Noor cites work on her introduction and her goal to use her creativity strength to find "new ways to draw in the reader." Through the process of trying multiple ways to begin the essay, she found that the most effective strategy for her was to provide background information on, and definitions of, closed and open adoptions. Noor discovered that she can still exercise her strength of creativity within a genre that she perceived as being confining and restrictive, that is, she used her strength in a new way.

In both her narrative frame for week 1 and Assignment 1, another writing challenge that Noor describes was finding her "inner voice":

It is also challenging to translate certain ideas and sentences in my head to English since the language structure is different from that in Arabic. It is a long systematic process from developing the idea in my head in Arabic, translating it to English, and then adjusting it to a certain style of writing.

\footnotetext{
${ }^{3}$ A closed adoption means there is no contact between the birth parents and the adoptive parents, while in open adoptions, birth parents and adoptive parents choose to include both parties in the adopted child's life.
} 
This challenge is exacerbated with writing her research paper when she laments in Assignment 4, her reflective journal:

I find it challenging to brain storm my ideas and finding the order and hierarchy in my research since I am overwhelmed by the things I read about the topic and want to include them. Thus, making it difficult for me to find what my argument is and what is the best method to convince my reader.

However, Noor used her spirituality strength as a way to organize ideas. For Noor, finding her "inner voice" is a complicated process. When reflecting on the first draft of the research essay in Assignment 4, Noor states, "The overuse, and abuse of voicing my opinion rather than supporting my argument with peer-reviewed articles, data, and experts' opinion weakened the claims I made." Noor's use of the pronoun "I" undergoes a transformation during the course of the semester. In her first assignment, Noor used "I" frequently throughout to discuss her experiences. In her research essay (Assignment 2), she removed the "I" when stating her opinion. For example, in her conclusion, she states,

Whether the vessel chosen is open or closed adoption a child has the right to learn the truth about his identity since day one. Manipulating the story and waiting until the child turns the legal age would only create self-acceptance and identity issues which might later lead to various mental disorders and cause depression.

She seems to feel more confident in stating her opinion after she has stated research supporting many sides of the issue of adoption, but finding an inner voice did not necessarily mean using "I" in her papers.

During week 3, Noor was asked to use her research to write a letter to the editor of a newspaper or magazine of her choosing. In her narrative frame, Noor explained that she used her strengths to find "smart" arguments and "accurate facts." In her letter, she responded to a previous article about an experiment conducted on triplets separated at birth. In her reflection about the letter (Assignment 4), she specifically mentions that she had read multiple articles about adoption and felt knowledgeable about the subject. She worked on the final draft in order to find an "accurate tone" and, in doing so, decided that her letter should be directed to "adoptive parents, and for that [she] kept the language simple and did not mention scientific terms used in the study like polygenic, eugenics, etc." Because she knew that adoption was a sensitive topic, Noor chose to include a quote in her letter from one of the actual triplets who was targeted in the study. She also decided an anecdote would be appropriate for the content, and she interpreted this as being "honest" about her description of the study in the letter. While Noor's purpose for writing was somewhat vague 
("inform the public and alarm parents to wake up"), she found some freedom and strength in writing about something with which she is deeply concerned.

Over the three-week intervention period, by actively thinking about her signature strengths, Noor altered some of her beliefs about writing. Instead of thinking about her writing in terms of rules and policies, she came to see it as more nuanced and complex. She understood that "writing in the field of design can look and feel very different like that of magazines, and design journals" (Assignment 4), but that there are choices within each genre of writing. Noor found room for creativity within the assignments, but the ways she drew on her creativity took on different forms in each context.

\section{After the Strengths Intervention}

The post-intervention narrative frame asked participants to reflect upon the experience of using signature strengths and to project forward as to how they might use them in the future. Noor's final post-intervention narrative frame was as follows:

This past month, I used my personal strength in new ways by introducing it to my life in new ways like my art. From this experience, I felt powerful. This is because I was able to use my strength efficiently. In my Writing class, I felt more productive. However, I still struggle with organizing my ideas since it does get overwhelming sometimes. Yet, from this experience, I have learned to get my mind off things and start after a short break. Still there are still so many ways for me to use my strengths! Among them are communicating with people in any form (art, conversations, writing).

A striking element of Noor's final narrative is her revelation that she was able to extend the use of her signature strengths to other areas of her life, such as her art, and that this extension resulted in positive outcomes, making her feel more powerful and productive. As a design major, art is central not only to her identity, but also to her profession. She admits to feeling overwhelmed at times but knowing how to use her strengths has taught her to reenergize by taking a break to re-center herself.

At the end of the study, we informed the participants of their anxiety scores from the pre- and post-intervention SLWAI and asked them to reflect on the differences between the pre-test and the post-test, if any. Our purpose in doing so was a form of member check (Maxwell, 2013) wherein the research participant reacts to the information obtained in the study. Noor's response to her reduction in anxiety scores on the SLWAI was as follows: 
Towards the beginning of the semester, I was uncertain of my English language skills. This was because I was not confident in my own voice. I tried to mask my opinion by using the passive voice. However, that made me realize that I was anxious to express my inner voice. After participating in the study [...], I had to face my anxiety and accept it so I can move on. I started using the active voice in my writing, which decreased the grade of my essay because I did not master the style well. However, after some practice, my grades became better and I was more confident in expressing my thoughts and my values to communicate to people my standard rather than shying away. And I feel like I have accomplished that since I went from a 72 to a [score of 51, a change of] -21 .

Rather than working on compensating for her deficiencies in her writing, Noor capitalized on signature strengths she already possessed to make the writing process easier, more enjoyable, and to gain confidence. Her teacher uses a very friendly teaching style, beginning class with a question used to create an open environment, group work activities, and thus students were encouraged to offer multiple viewpoints in class discussions. Noor said that the effect extended to the rest of her life and art, leading her to feel more powerful, productive, and energized.

Noor's specific approach to implementing the Signature Strengths PPI supports the need to assess the person-activity fit. Lyubomirsky and Layous (2013) presented the factors that mediate the effectiveness of PPIs, including (1) the details of the specific PPI; (2) the characteristics of the person using it; (3) the degree of 'fit' between the person and the activity; and (4) a consideration of the specific processes that are engaged. The present results support the idea that assessing the efficacy of the PPI can be done at the individual level, in a detailed analysis of the process used to implement the PPI and tailor it to the individual. Noor's quantitative data showed that the PPI was unusually effective for her, she showed a remarkable reduction in writing anxiety, and the above analysis suggests that it fit her needs remarkably well.

\section{Conclusion}

Perhaps the most appropriate conclusion of this study is that the PPI intervention can reduce writing anxiety for some learners but not others. For at least one individual, this occurred in a dramatic fashion. That is not to say the PPI will work for everyone. One of the lessons emerging from this study is the need to examine in detail the fit between the individual and the PPI 
activity and to document the process by which it exerts its effect. In fact, one of the most significant pedagogical implications emerging from this study is that interventions, such as learning tasks, assessment tools, feedback, and other teaching/learning mechanisms, are most effective when personalized to meet the individual needs of the learner. The present results reinforced the benefits of an individual-level experimental approach to analyzing the efficacy of interventions. We know from previous investigations that even the most successful inventions will not affect all persons in the same way, and some persons might not engage with the PPI at all.

Csikszentmihalyi (1991, p. xi) poetically suggests, "[...] a joyful life is an individual creation that cannot be copied from a recipe." In more practical research terms, Molenaar and Campbell (2009) argue forcefully what virtually every methodologist knows - because of intra-group variability and aggregation of data across persons, group level results, including differences in means showing change over time, cannot be assumed to apply to any individual, even those persons within the group that produced the data. Further, data collected on the efficacy of an intervention in one domain (writing) might not transfer to another domain (speaking), and results might also vary substantially across teaching contexts, participant age groups, cultures, and teacher characteristics.

The implications of these methodological tenets can often be overlooked in asking whether an intervention 'worked.' In practical terms it means that we must approach evaluating interventions at each implementation, cautiously, and without over-generalizing. Therefore, in conclusion, we present Noor's case as one example where using signature strengths in a new way led to a reduction in anxiety because the PPI itself fit both the person and the context in which she was studying.

\section{References}

Aki, O. (2006). Is emotional intelligence or mental intelligence more important in language learning? Journal of Applied Sciences, 6(1), 66-70.

Barkhuizen, G., \& Wette, R. (2008). Narrative frames for investigating the experiences of language teachers. Auckland, NZ: Elsevier Ltd.

Biswas-Diener, R., Kashdan, T. B., \& Minhas, G. (2011). A dynamic approach to psychological strength development and intervention. The Journal of Positive Psychology, 6(2), 106-118.

Byrnes, H. (2018). Advanced-level grammatical development in instructed SLA. In P. Malovrh \& A. Benati (Eds.), The handbook of advanced proficiency in second language acquisition (pp. 133-156). Malden, MA: Wiley-Blackwell.

Cheng, Y. S. (2002). Factors associated with foreign language writing anxiety. Foreign Language Annals, 35(6), 647-656. 
Cheng, Y. S. (2004). A measure of second language writing anxiety: Scale development and preliminary validation. Journal of Second Language Writing, 13(4), 313-335.

Cheng, Y. S., Horwitz, E. K., \& Schallert, D. L. (1999). Language anxiety: Differentiating writing and speaking components. Language Learning, 49(3), 417-446.

Csikszentmihalyi, M. (1991). Flow: The psychology of optimal experience. New York: Harper Perennial.

Dewaele, J.-M., \& Dewaele, L. (2017). The dynamic interactions in foreign language classroom anxiety and foreign language enjoyment of pupils aged 12 to 18. A pseudo-longitudinal investigation. Journal of the European Second Language Association, 1(1), 12-22.

Eid, M., \& Diener, E. (1999). Intraindividual variability in affect: Reliability, validity, and personality correlates. Journal of Personality and Social Psychology, 76(4), 662-676. https:// doi.org/10.1037/0022-3514.76.4.662

Findlow, S. (2006). Higher education and linguistic dualism in the Arab Gulf. British Journal of Sociology of Education, 27, 19-36.

Gabryś-Barker, D., \& Gałajda, D. (Eds.) (2016). Positive psychology perspectives on foreign language learning and teaching. New York: Springer.

Ghielen, S. T. S., van Woerkom, M., \& Meyers, C. M. (2017). Promoting positive outcomes through strengths interventions: A literature review. Journal of Positive Psychology, 13, 573-585. https://doi.org/10.1080/17439760.2017.1365164

Gregersen, T., \& MacIntyre, P. D. (2014). Capitalizing on learners' individuality: From principle to practice. Bristol, UK: Multilingual Matters.

Gregersen, T., MacIntyre, P. D., Finegan, K. H., Talbot, K., \& Claman, S. (2014). Examining emotional intelligence within the context of positive psychology interventions. Studies in Second Language Learning and Teaching, 4, 327-353.

Gregersen, T., MacIntyre, P. D., \& Macmillan, N. (2020). Dealing with the emotions of teaching abroad: Searching for silver linings in a difficult context. In C. Gkonou, J.-M. Dewaele, \& J. King (Eds.), The emotional rollercoaster of language teaching (pp. 228-246). Bristol, UK: Multilingual Matters.

Gregersen, T., MacIntyre, P. D., \& Meza, M. (2016). Positive psychology exercises build social capital for language learners: Preliminary evidence. In P. D. MacIntyre, T. Gregersen, \& S. Mercer (Eds.), Positive psychology in SLA (pp. 147-167). Bristol, UK: Multilingual Matters.

Hefferon, K., Ashfield, A., Waters, L., \& Synard, J. (2017). Understanding optimal human functioning-The 'call for qual' in exploring human flourishing and well-being. Journal of Positive Psychology, 12, 211-219.

Helgesen, M. (2018). English teaching and the science of happiness: Positive psychology communication activities for language learners. Tokyo: Abax.

Horwitz, E. K. (2017). On the misreading of Horwitz, Horwitz, and Cope (1986) and the need to balance anxiety research and the experiences of anxious language learners. In C. Gkonou, M. Daubney, \& J.-M. Dewaele (Eds.), New insights into language anxiety: Theory, research and educational implications (pp. 31-47). Bristol: Multilingual Matters.

Horwitz, E. K., Horwitz, M. B., \& Cope, J. A. (1986). Foreign language classroom anxiety. Modern Language Journal, 70, 125-132.

Koydemir, S., \& Sun-Selış1k, Z. E. (2016). Well-being on campus: Testing the effectiveness of an online strengths-based intervention for first year college students. British Journal of Guidance \& Counselling, 44(4), 434-446. http://dx.doi.org/10.1080/03069885.2015.1110562

Lazarus, R. S. (2003). Does the positive psychology movement have legs? Psychological Inquiry, 14(2), 93-109. 
Lee, S. Y., \& Krashen, S. D. (1997). Writing apprehension in Chinese as a first language. ITLInternational Journal of Applied Linguistics, 115(1), 27-37.

Linley, P. A., Maltby, J., Wood, A. M., Joseph, S., Harrington, S., Peterson, C., \& Seligman, M. E. (2007). Character strengths in the United Kingdom: The VIA inventory of strengths. Personality and Individual Differences, 43(2), 341-351.

Lyubomirsky, S., \& Layous, K. (2013). How do simple positive activities increase well-being? Current Directions in Psychological Science, 22(1), 57-62.

Lyubomirsky, S., Dickerhoof, R., Boehm, J. K., \& Sheldon, K. M. (2011). Becoming happier takes both a will and a proper way: An experimental longitudinal intervention to boost well-being. Emotion, 11(2), 391.

MacIntyre, P. D., \& Gardner, R. C. (1991). Methods and results in the study of anxiety and language learning: A review of the literature. Language Learning, 41(1), 85-117.

MacIntyre, P. D. (1999). Language anxiety: A review of the research for language teachers. In D. J. Young (Ed.), Affect in foreign language and second language teaching: A practical guide to creating a low-anxiety classroom atmosphere (pp. 24-45). Boston: McGraw-Hill.

MacIntyre, P. D. (2017). An overview of language anxiety research and trends in its development. In C. Gkonou, M. Daubney, \& J.-M. Dewaele (Eds.), New insights into language anxiety: Theory, research and educational implications (pp. 11-30). Bristol: Multilingual Matters.

MacIntyre, P. D., \& Mercer, S. (2014). Introducing positive psychology to SLA. Studies in Second Language Learning and Teaching, 2, 153-172. https://doi.org/10.14746/ssllt.2014.4.2.2

MacIntyre, P. D., Gregersen, T., \& Mercer, S. (2019). Setting an agenda for positive psychology. Modern Language Journal, 103(1), 262-274.

McGrath, R. E. (2015). Integrating psychological and cultural perspectives on virtue: The hierarchical structure of character strengths. The Journal of Positive Psychology, 10(5), 407-424. https://doi.org/10.1080/17439760.2014.994222

McGrath, R. E. (2016). Measurement invariance in translations of the VIA Inventory of Strengths. European Journal of Psychological Assessment, 32(3), 187-194. https://doi. org/10.1027/1015-5759/a000248

McGrath, R. E., \& Wallace, N. (2019). Cross-validation of the via inventory of strengths-revised and its short forms. Journal of Personality Assessment. https://doi.org/10.1080/00223891 .2019 .1705465

Maxwell, J. (2013). Qualitative research design. Thousand Oaks, CA: Sage.

Molenaar, P. C., \& Campbell, C. G. (2009). The new person-specific paradigm in psychology. Current Directions in Psychological Science, 18(2), 112-117.

Mongrain, M., \& Anselmo-Matthews, T. (2012). Do positive psychology exercises work? A replication of Seligman et al. (2005). Journal of Clinical Psychology, 68(4), 382-389.

Peterson, C. (2006). A primer in positive psychology. New York: Oxford University Press.

Peterson, C., \& Seligman, M. E. P. (2004). Character strengths and virtues: A handbook and classification. New York: Oxford University Press and Washington, DC: American Psychological Association.

Rath, T. (2007). StrengthsFinder 2.0. New York: Gallup Press.

Schutte, N. S., \& Malouff, J. M. (2018). The impact of signature character strengths interventions: A meta-analysis. Journal of Happiness Studies, 20, 1179-1196. https://doi.org/10.1007/ s10902-018-9990-2

Seligman, M. E. P. (2002). Authentic happiness: Using the new positive psychology to realize your potential for lasting fulfilment. New York: Free Press.

Seligman, M. E., \& Csikszentmihalyi, M. (2000). Positive psychology: An Introduction. American Psychologist, 55(1): 5-14. https://doi.org/10.1037/0003-066X.55.1.5 
Seligman, M. E., Steen, T. A., Park, N. \& Peterson, C. (2005). Positive psychology progress: Empirical validation of interventions. American Pyschological, 60(5): 410-421. https://doi.org/10.1037/0003-066X.60.5.410

Sin, N. L., \& Lyubomirsky, S. (2009). Enhancing well-being and alleviating depressive symptoms with positive psychology interventions: A practice-friendly meta-analysis. Journal of Clinical Psychology, 65(5), 467-487.

Teimouri, Y., Goetze, J., \& Plonsky, L. (2019). Second language anxiety and achievement: A meta-analysis. Studies in Second Language Acquisition, 41, 363-387.

Valizadeh, M. R., \& Alavinia, P. (2012). Listening comprehension performance viewed in the light of emotional intelligence and foreign language listening anxiety. English Language Teaching, 6(12), 11-26.

VIA Institute on Character (2019). Homepage. Retrieved from www.viacharacter.org

Woodworth, R. J., O’Brien-Malone, A., Diamond, M. R., \& Schüz, B. (2016). Happy days: Positive psychology interventions effects on affect in an N-of-1 trial. International Journal of Clinical and Health Psychology, 16(1), 21-29.

Zarafshan, M., \& Ardeshiri, M. (2012). The relationship between emotional intelligence, language learning strategies and English proficiency among Iranian EFL university students. The Journal of Educational and Instructional Studies in the World, 2(3), 105-114.

Appendix A

\section{Narrative Frames}

\section{Pre-intervention Narrative Frame: My Strengths Story}

In my Writing class, I have a difficult time trying to

The main reason for this is

However, I feel I excel in

One of my personal strengths is I have used

it in the past to

This week I will use my strength to help me in my writing and in my writing class by

For each of the remaining three weeks I will try to use my personal strength in a new way by: 1)

2)

3)

\section{Post-intervention Narrative Frame}

This past month, I used my personal strength in new ways by

From this experience, I felt

This is because

In my Writing class, I felt more 
However, I still struggle with

. Yet, from this experience, I have

learned Still, there are still so

many ways for me to use my strengths!! Among them are

\section{3. "During intervention" Narrative Frame}

MY TOP FIVE PERSONAL STRENGTHS ARE:

1.

2.

3.

4.

5.

Weekly Strength Report:

\section{Sunday}

The strength I used was

I used this strength in my writing by

After doing this, I felt

\section{Monday}

The strength I used was

I used this strength in my writing by

After doing this, I felt

\section{Tuesday}

The strength I used was

I used this strength in my writing by

After doing this, I felt

\section{Wednesday}

The strength I used was

I used this strength in my writing by

After doing this, I felt

\section{Thursday}

The strength I used was

I used this strength in my writing by

After doing this, I felt 
Tammy Gregersen, Peter D. MacIntyre, Rachel Buck

\title{
Die Verwendung von Charakterstärken zur Bekämpfung von Schreibangst in Englisch
}

\begin{abstract}
Zusammenfassung
Die positive Psychologie wurde in die Literatur der angewandten Linguistik mit dem allgemeinen Ziel eingeführt, die Erfahrungen von Sprachlernern und -lehrern durch eine Vielzahl von Interventionen zu verbessern (MacIntyre \& Mercer, 2014; Gabryś-Barker \& Gałajda, 2016). „Das Ziel der positiven Psychologie ist es, einen Wandel in der Psychologie zu katalysieren, der sich nicht mehr nur damit beschäftigt, die schlechtesten Dinge im Leben zu reparieren, sondern auch die besten Qualitäten im Leben aufzubauen“ (Seligman \& Csikszentmihalyi, 2000, S. 5). Ein wichtiger Beitrag dieses jungen Gebiets ist eine Reihe von empirisch getesteten, positiv-psychologischen Interventionen (PPI), die nachweislich positive Emotionen verstärken, Disstress reduzieren und/oder das Wohlbefinden verbessern (Seligman, Steen, Park, \& Peterson, 2005; Sin \& Lyubormirsky, 2009). In der vorliegenden Studie wird eine Anwendung von PPI untersucht, deren Schwerpunkt in der Nutzung von Charakterstärken als einer Möglichkeit, die Sprachangst zu behandeln, liegt. Anhand einer Fallstudie wird aufgezeigt, wie diese Intervention für die Studierenden von Vorteil war.
\end{abstract}

Schlüsselwörter: Fremdsprachenangst, positiv-psychologische Interventionen (PPI), VIA Strengths Inventory 
